\title{
Upgrading Wastewater Treatment Plant to Obtain Drinking Water
}

\author{
Djamel Ghernaout ${ }^{1,2 *}$, Noureddine Elboughdiri1,3 \\ ${ }^{1}$ Chemical Engineering Department, College of Engineering, University of Ha'il, Ha'il, KSA \\ ${ }^{2}$ Chemical Engineering Department, Faculty of Engineering, University of Blida, Blida, Algeria \\ ${ }^{3}$ Département de Génie Chimique de Procédés, Laboratoire Modélisation, Analyse, et Commande des systèmes, Ecole Nationale \\ d’Ingénieurs de Gabès (ENIG), Gabès, Tunisia \\ Email: ^djamel_andalus@hotmail.com
}

How to cite this paper: Ghernaout, D. and Elboughdiri, N. (2019) Upgrading Wastewater Treatment Plant to Obtain Drinking Water. Open Access Library Journal, 6: e5959. https://doi.org/10.4236/oalib.1105959

Received: November 26, 2019

Accepted: December 24, 2019

Published: December 27, 2019

Copyright ( 2019 by author(s) and Open Access Library Inc.

This work is licensed under the Creative Commons Attribution International License (CC BY 4.0).

http://creativecommons.org/licenses/by/4.0/ (c) (†) Open Access

\begin{abstract}
With a growing population and expansion, societies worldwide brave lack water for drinking supply. Undeveloped sources of water should be specified to diminish such issues. Direct potable reuse is a supply-side procedure that can enhance the sustainability and reliability of water supplies via recuperating potable water from wastewater. This work assesses the perspective of upgrading the wastewater treatment plants to obtain potable water. Treating wastewater at the highest level of purity to guarantee the drinking water supply is the best approach to avoid the pollution expansion from wastewater even if it is partially treated to minimize its toxic impacts and provide water for irrigation and industrial use purposes. Treating wastewater at present in the actual wastewater treatment plants should be urgently upgraded to provide potable water through adding processes steps such as nanofiltration, reverse osmosis, and adsorption on activated carbon. Evidently, there is an additional cost for these sophisticated techniques to pay for the better future of the humankind. Finally, from the authors' point of view, treating wastewater must be continuously improved by using more and more developed techniques and consuming directly treated wastewater as potable water must be only considered as the final issue in the case of hard shortage situations for security reasons.
\end{abstract}

\section{Subject Areas}

Chemical Engineering \& Technology, Hydrology

\section{Keywords}

Water Reuse, Direct Potable Reuse, Water Scarcity, Membrane Processes, 
Wastewater Treatment, Drinking Water

\section{Introduction}

Wastewater treatment is a series of processes employed to eliminate pollutants from wastewater (or sewage) and transform it into an effluent that may be: 1) restored to the water cycle with a lower effect on the environment [1] [2] or, 2) directly reused [3] [4]. The last is known as water reclamation as treated wastewater may be employed for different aims [5] [6]. The remediation operation happens in a Wastewater Treatment Plant (WWTP), usually known as a Water Resource Recovery Facility (WRRF) or a Sewage Treatment Plant (STP). Contaminants in urban wastewater (households and small industries) are eliminated or decomposed [7] [8]. Treating wastewater is a portion of the overarching domain of sanitation [9] [10] [11]. Moreover, sanitation comprises the management of human waste and solid waste as well as stormwater (drainage) management [12]. By-products from WWTPs, like screenings, grit and sewage sludge are usually treated in a WWTP [13] [14] [15].

This work briefly reviews the wastewater treatment technologies from the perspective of upgrading WWTP to obtain potable water.

\section{Disposal or Reuse}

Even if disposal or reuse happens next remediation, it should be thought about primarily. As disposal or reuse are the aims of handling wastewater, disposal or reuse choices are the foundation for treatment solutions. Passable pollutant concentrations can change following the kind of employment or site of disposal. Carriage costs usually render passable pollutant concentrations following the site of disposal; however, costly remediation needs can promote the choice of a disposal site following pollutant concentrations [16]. Ocean disposal is related to international treaty requirements. International treaties may also regulate disposal into rivers crossing international borders. Water bodies completely inside the jurisdiction of a single nation may be subject to regulations of multiple local governments. Passable pollutant concentrations can change largely between various jurisdictions for disposal of wastewater to evaporation ponds, infiltration basins, or injection wells [8].

\section{Technologies}

Biological techniques are usually used in handling wastewater. Such methods may comprise aerated lagoons, activated sludge or slow sand filters. Wastewater is transported to a WWTP via convenient pipes and infrastructure and the technology itself must be subject to regulation and controls. Handling wastewater is realized via separation of solids from liquids, frequently through sedimentation. Through gradually transforming dissolved material into solids, frequently 
a biological floc [17] [18] [19], which is then settled out, an effluent stream of augmenting purity is formed [8] [20].

\subsection{Phase Separation}

Phase separation transforms contaminants into a non-aqueous phase. Phase separation may take place at in-between levels in a remediation succession to eliminate solids formed throughout oxidation. Grease and oil may be recuperated for fuel or saponification. Solids usually need dewatering of sludge in a WWTP. Elimination choices for dried solids change with the kind and concentration of pollutants eliminated from the water [8].

\subsubsection{Sedimentation}

Solids such as stones, grit, and sand may be eliminated from wastewater via gravity if density distinctions are enough to beat dispersion via turbulence. Gravity separation of solids is the main remediation of sewage, where the unit process is named "primary settling tanks" or "primary sedimentation tanks". It is likewise largely employed for dealing with various wastewaters. Solids that are denser than water will collect at the bottom of quiescent settling tanks. More sophisticated clarifiers furthermore possess skimmers to together eliminate floating grease such as soap scum and solids such as feathers or wood chips [8].

\subsubsection{Filtration}

Usually, suspended solids and colloidal suspensions of fine solids can, frequently following some form of coagulation [21] [22] [23] [24] [25], be eliminated via filtration by fine physical barriers differentiated from coarser screens or sieves by the capacity to eliminate solids smaller than the openings through which the water passes [26]. Diverse kinds of water filters eliminate pollutants during chemical or biological processes defined below [8] [27].

\subsection{Oxidation}

Oxidation decreases the Biochemical Oxygen Demand (BOD) of wastewater and can lessen the poisoning of several contaminants. Secondary treatment transforms organic compounds [28] into carbon dioxide, water, and biosolids. Chemical oxidation is largely employed for killing microorganisms in water [8] [29] [30] [31] [32].

\subsubsection{Biochemical Oxidation}

Secondary treatment via biochemical oxidation of dissolved and colloidal organic compounds [33] is largely employed in sewage treatment. Biological oxidation will preferentially eliminate organic compounds [34] beneficial as a food supply for the treatment ecosystem. The concentration of some less digestible compounds may be decreased through co-metabolism. Elimination performance is restricted by the minimum food concentration needed to endure the treatment ecosystem [8]. 


\subsubsection{Chemical Oxidation}

Chemical (including electrochemical [35]-[46]) oxidation is employed to eliminate several enduring organic contaminants [47] [48] [49] [50] and concentrations remaining after biochemical oxidation. Killing microorganisms through chemical oxidation demobilizes bacteria and microbial pathogens via injecting ozone, chlorine or hypochlorite to wastewater [8] [51] [52] [53].

\subsection{Polishing}

Polishing alludes to treatments performed after the above techniques. Such treatments may likewise be employed separately for several industrial wastewaters. Chemical reduction or $\mathrm{pH}$ adjustment reduces the chemical reactivity of wastewater after chemical oxidation. Carbon filtering eliminates residual pollutants through chemical adsorption onto activated carbon (AC). Filtration via sand (calcium carbonate) or fabric filters is the most frequent technique employed in urban wastewater treatment [8].

\section{Potable Reuse Case Studies}

Through the world, there are several successful cases for water reuse such as: 1) Windhoek (Namibia, Goreangab Reclamation Plant), 2) California (Groundwater Replenishment System in Orange County, USA), 3) Virginia (Upper Occoquan Service Authority Potable Reuse Project in Virginia, USA), 4) Singapore (Water reuse in Singapore-NEWater), 5) Perth(Australia, Groundwater Replenishment), 6) Texas (Direct Potable Water Reuse in Texas, USA), and 7) South Africa (Water Reuse in South Africa: The eMalahleni Water Reclamation Plant) [54].

More details about these case studies may be found elsewhere [54].

\section{Treating Municipal Wastewater: From Consolidated to New Advanced Treatment Techniques}

Municipal wastewater treatment plants (WWTPs) remain between the major anthropogenic sources for the release of contaminants of emerging concern (CECs) into nature [55]. This may conduct to poisonous and opposite impacts on aquatic organisms and thus on human beings. Regrettably, WWTPs are not planned to eliminate CECs; moreover, secondary (such as traditional activated sludge process, CAS) and tertiary (like filtration and disinfection [56]-[61]) stages are not efficient in eliminating the most of CECs coming in WWTP. Consequently, various advanced treatment technologies have been examined for eliminating CECs from wastewater, comprising consolidated (that is, AC adsorption, ozonation, and membranes [62] [63]) and novel (like advanced oxidation processes (AOPs) [64]) techniques. Rizzo et al. [65] reviewed the state of the art and the best available technologies for the advanced treatment of municipal wastewater. Especially, they deeply discussed the data [66] obtainable on consolidated (ozonation, AC and membranes [67]) and novel advanced treatment methods (fundamentally AOPs) to assess (Figure 1): 1) their performance in 


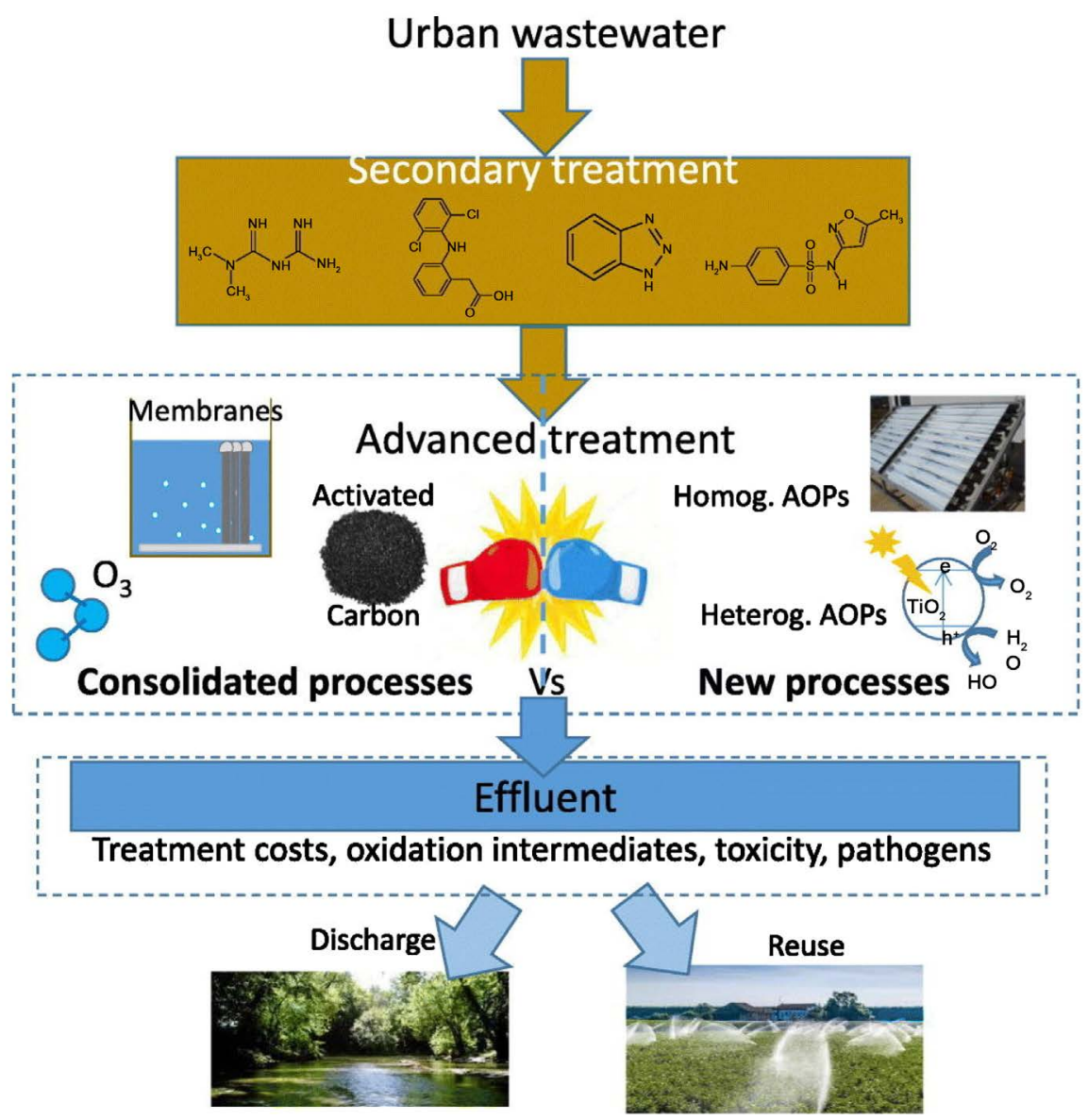

Figure 1. Municipal wastewater treatment from yesterday to tomorrow [65].

eliminating CECs from wastewater, 2) benefits and inconvenients, 3) likely barriers to using AOPs, 4) practical restrictions and mid to long-term estimations for employing heterogeneous processes, and 5) a technical and economic comparison between the numerous processes/technologies.

Rizzo et al. [65] concluded that:

1) Consolidated advanced urban wastewater treatment techniques, to be specific AC adsorption, ozonation, and filtration by nanofiltration (NF) or reverse osmosis (RO) membranes [68], can efficiently eliminate CECs. Numerous facilities using $\mathrm{AC}$ adsorption and ozonation have lately been put into action cost-efficiently at full scale in Germany and Switzerland. Filtration with narrow membranes [69] as employed in $\mathrm{NF}$ or $\mathrm{RO}$ was observed to be more cost-intensive. However, RO membranes [70] have been applied on a full scale in drinking reuse programs in the United States of America, Singapore, and Australia thanks to the supplementary advantage given concerning salinity and metal removal.

2) In geographical regions with elevated yearly average solar irradiation [71] (between latitude $40^{\circ} \mathrm{N}$ and $40^{\circ} \mathrm{S}$ ), solar-driven AOPs seem competitive with different advanced treatment technologies for CECs reduction from municipal wastewater. The identical situation subsists for several innovative processes and 
fresh integrations of present techniques, which usually have been tested only at small-scale or under non-realistic source water conditions so far.

3) Removing CECs from wastewater via AOPs is a function of the working indicators, the matrix composition, and the elimination pathways taking place through the usage of each treatment technique. If implementing ozonation or AOPs, the formation of oxidation or transformation products with important biological impacts causes the requirement to carry out ecotoxicological investigations to assess the impact of such fresh products. A post-treatment using sand filters or AC has been found an appropriate design to beat with this problem following ozonation; however, it elevates treatment costs.

4) The large local diversity of CECs and of the water matrix render optimization fundamental for each implementation (adsorbent and/or flocculants selection [72] [73], choice of membranes [74] [75], injection modes, systems dispositions, mixing parameters, etc.). This shows the necessity for knowledge systematization and development of tools for the prediction of CECs behavior in wastewater treatment [76].

5) The absence of comparative studies among consolidated (AC adsorption and ozonation) and novel methods (that is fresh AOPs) restrain the categorical estimate of the most convenient and cost-effective choices for advanced treatment of municipal wastewater. Besides, site-specific restrictions (like availability of space and solar energy [77], cost of electricity) may conduct to diverse deductions for two various sites. Most importantly, these comparative examinations must be conceived and executed via considering diverse crucial endpoints for secure effluent discharge or reuse, like CECs removal, effluent poisoning, bacteria-killing [78], by-products reduction or removal, antibiotic resistance control, and treatment cost.

\section{Endocrine-Disruptor Compounds (EDCs) Removal}

Hormone active agents make a serious category of contaminants [79]. Between them, those agents that imitate the work of estrogens on target cells and are part of the group of endocrine-disruptor compounds (EDCs) are named estrogenic EDCs (Figure 2). Subjection to such complexes occasions several unfavorable impacts, comprising breast cancer, infertility, and animal hermaphroditism. Nevertheless, mostly in underdeveloped countries, restricted attempts have been performed to alert people concerning this grave problem, elucidate the procedures of reducing exposure, and improve appropriate and performant alleviation programs in diverse fields and in several environments. For example, employing bioremediation methods able to converting EDCs into environmentally friendly chemicals has been little examined. A large variety of estrogen-degrading microorganisms could be employed to incubate such techniques, which comprise bioremediation methods for EDCs that may be applied in biological filters for the post-treatment of wastewater effluent. Vilela et al. [80] listed issues linked with EDCs, firstly estrogenic EDCs, comprising exposure as well as the current 


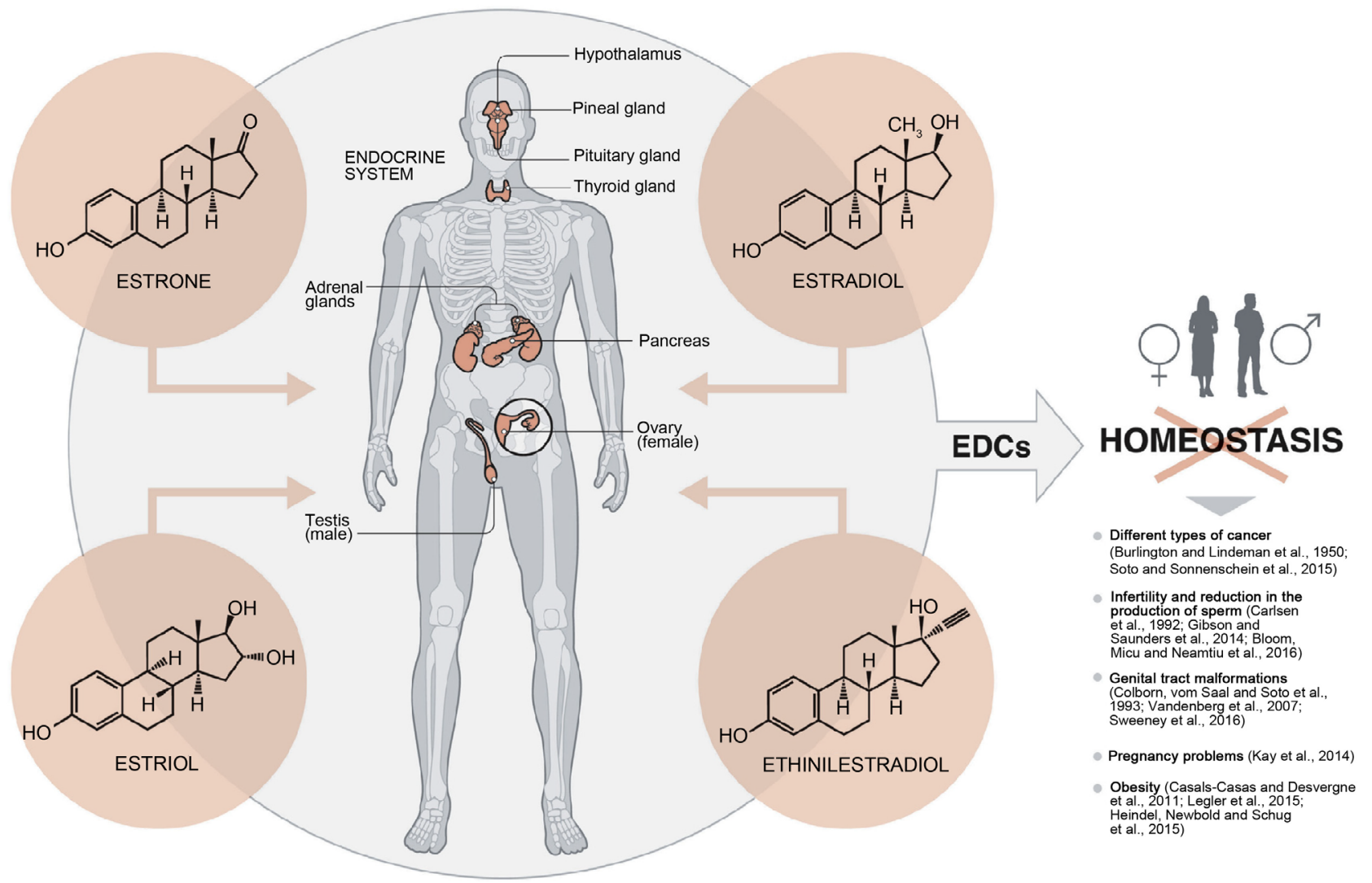

Figure 2. Schematic representation of estrogens estrone (E1), estradiol (E2), estriol (E3) and ethinylestradiol (EE2) activities in the endocrine system affecting the body's homeostasis [80].

case of comprehension and the influences of natural and synthetic hormones and estrogenic EDCs on living organisms. They presented possible biotechnological plans for EDC biodegradation and proposed new treatment techniques for reducing the presence of EDCs in the nature (Figure 3).

Indeed, it was established that five bacterial strains isolated from activated sludge were capable to decompose E2, and a strain of Bacillus subtilis was capable to decompose E2 in 4 days and diminish the concentration of estrogenic compounds [81]. This bio-decomposition capacity could be helpful in diminishing the global estrogenic action in nature, by eliminating the four main estrogenic compounds existing in wastewater by bio-augmentation plans. This method may even be used in integration with additional actual techniques implying filters and treatment systems. It seems that the bio-decomposition of estrogens is an encouraging solution to remove such compounds in nature. In addition, it may be employed in integration with actual treatment systems [80].

Following such findings, to reduce more and finally eliminate estrogens in the water mediums, an estrogen-specific method could be implemented in WWTPs in integration with a biological filter [82]. The biofilter must include the essential species of estrogen-degrading bacteria and could be used through the final treatment stage, to guarantee an effluent that is free of EDC poisoning. The proposed plan for this substitutional treatment employing biodegradation is 


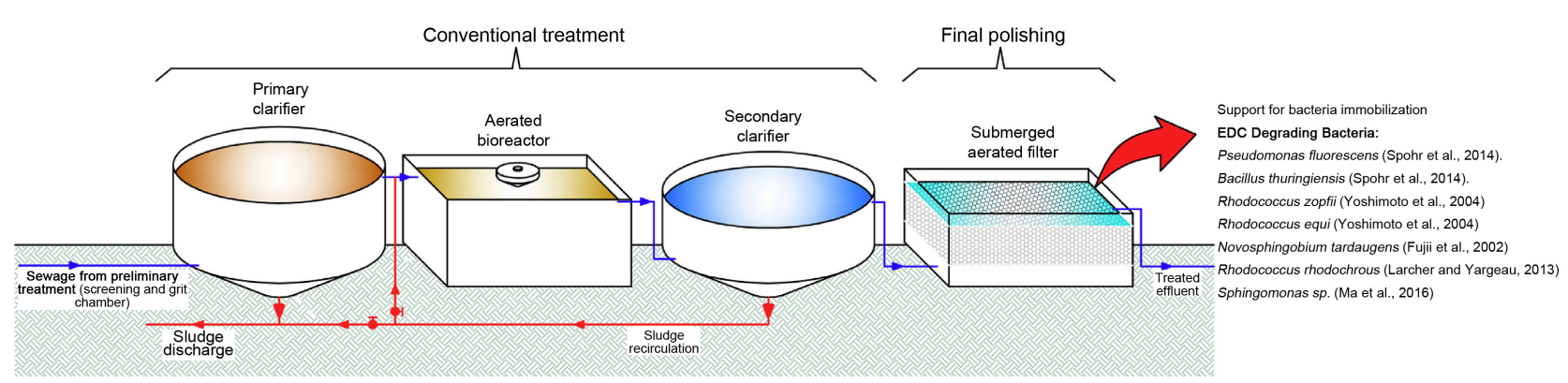

Figure 3. Schematic representation of the proposed wastewater-treatment process with the use of the biological filter as a step for the removal of estrogens [80].

illustrated in Figure 3. The plan presents the simplified treatment method for an effluent inflow, where the effluent firstly passes through preliminary and traditional treatment [83] [84] (primary decanter, activated biological reactor and secondary decanter). In addition to such stages, the effluent would undergo a post-treatment stage termed "final polishing" (Figure 3), which implies the biological filter. This filter is abacterial support structure to which organisms [85] [86] [87] [88] can adhere, and it works in aerated [89] and submerged environments. The principal estrogen-degrading bacterial groups would attach to this support. Subsequently, the totally treated effluent without the existence, or with diminished quantities, of EDCs could be liberated into water mediums [80] [90] [91] [92].

\section{Conclusions}

The main points drawn from this work may be given as:

1) Direct potable reuse of wastewater is more and more being seen as a solution source of water for satisfying societies' future water supply necessities. This attention is attributed to diverse parameters comprising ameliorations in treating wastewater, enhanced comprehension of the chemistry and toxicology of micropollutants in water, and decreases in treatment costs. One more crucial parameter has been elevated public acceptance of the idea as a consequence of augmented consciousness of the shortage of various sources of supply and the exposure of water resources to the impacts of drought and climate alteration.

2) Treating wastewater at the highest level of purity to guarantee the drinking water supply remains the best approach to avoid the pollution expansion from wastewater even if it is partially treated to minimize its toxic impacts and provide water for irrigation and industrial use purposes. Treating wastewater at present in the actual wastewater treatment plants should be urgently upgraded to provide potable water through adding processes steps such as NF, RO, and adsorption on AC. Evidently, there is an additional cost for these sophisticated techniques to pay for the better future of the humankind.

3) Great alertness to hazards caused by pollutants will stay fundamental and much research necessities to be performed to define and keep exercises that assure public integrity. Worker guidance remains essential, as will investigation on 
efficient detection, treatment, and control.

\section{Conflicts of Interest}

The authors declare no conflicts of interest regarding the publication of this paper.

\section{References}

[1] Ghernaout, D., Aichouni, M. and Alghamdi, A. (2018) Overlapping ISO/IEC 17025:2017 into Big Data: A Review and Perspectives. International Journal of Science and Qualitative Analysis, 4, 83-92.

[2] Ghernaout, D., Aichouni, M., Alghamdi, A. and AitMessaoudene, N. (2018) Big Data: Myths, Realities and Perspectives-A Remote Look. American Journal of Information Science and Technology, 2, 1-8. https://doi.org/10.11648/j.ajist.20180201.11

[3] Al Arni, S., Amous, J. and Ghernaout, D. (2019) On the Perspective of Applying of a New Method for Wastewater Treatment Technology: Modification of the Third Traditional Stage with Two Units, One by Cultivating Microalgae and Another by Solar Vaporization. Int. Journal of Environmental Science and Natural Resources, 16, Article ID: 555934. https://doi.org/10.19080/IJESNR.2019.16.555934

[4] Ghernaout, D. (2013) The Best Available Technology of Water/Wastewater Treatment and Seawater Desalination: Simulation of the Open Sky Seawater Distillation. Green and Sustainable Chemistry, 3, 68-88. https://doi.org/10.4236/gsc.2013.32012

[5] Vo, P.T., Ngo, H.H., Guo, W., Zhou, J.L., Nguyen, P.D., Listowski, A. and Wang, X.C. (2014) A Mini-Review on the Impacts of Climate Change on Wastewater Reclamation and Reuse. Science of the Total Environment, 494-495, 9-17. https://doi.org/10.1016/j.scitotenv.2014.06.090

[6] Adewumi, J.R., Ilemobade, A.A. and Van Zyl, J.E. (2010) Treated Wastewater Reuse in South Africa: Overview, Potential and Challenges. Resources, Conservation \& Recycling, 55, 221-231. https://doi.org/10.1016/j.resconrec.2010.09.012

[7] Uche, J., Martínez-Gracia, A., Círez, F. and Carmona, U. (2015) Environmental Impact of Water Supply and Water Use in a Mediterranean Water Stressed Region. Journal of Cleaner Production, 88, 196-204. https://doi.org/10.1016/j.jclepro.2014.04.076

[8] Wikipedia (2019) Wastewater Treatment. https://en.wikipedia.org/wiki/Wastewater_treatment

[9] Ghernaout, D. (2018) Magnetic Field Generation in the Water Treatment Perspectives: An Overview. International Journal of Advanced and Applied Sciences, 5, 193-203. https://doi.org/10.21833/ijaas.2018.01.025

[10] Ghernaout, D. (2018) Increasing Trends towards Drinking Water Reclamation from Treated Wastewater. World Journal of Applied Chemistry, 3, 1-9.

https://doi.org/10.11648/j.wjac.20180301.11

[11] Ghernaout, D. (2017) Water Reuse (WR): The Ultimate and Vital Solution for Water Supply Issues. International Journal of Sustainable Development Research, 3, 36-46. https://doi.org/10.11648/j.ijsdr.20170304.12

[12] Furlong, C., De Silva, S., Gan, K., Guthrie, L. and Considine, R. (2017) Risk Management, Financial Evaluation and Funding for Wastewater and Stormwater Reuse Projects. Journal of Environmental Management, 191, 83-95. https://doi.org/10.1016/j.jenvman.2017.01.007 
[13] Ghernaout, D., Elboughdiri, N. and Ghareba, S. (2019) Drinking Water Reuse: One-Step Closer to Overpassing the "Yuck Factor". Open Access Library Journal, 6, e5895. https://doi.org/10.4236/oalib.1105895

[14] Ghernaout, D., Elboughdiri, N. and Al Arni, S. (2019) Water Reuse (WR): Dares, Restrictions, and Trends. Applied Engineering, 3, 159-170.

[15] Ghernaout, D., Ghernaout, B. and Naceur, M.W. (2011) Embodying the Chemical Water Treatment in the Green Chemistry: A Review. Desalination, 271, 1-10. https://doi.org/10.1016/j.desal.2011.01.032

[16] Herman, J.G., Scruggs, C.E. and Thomson, B.M. (2017) The Costs of Direct and Indirect Potable Water Reuse in a Medium-Sized Arid Inland Community. Journal of Water Process Engineering, 19, 239-247. https://doi.org/10.1016/j.jwpe.2017.08.003

[17] Ghernaout, D. and Ghernaout, B. (2012) Sweep Flocculation as a Second Form of Charge Neutralisation: A Review. Desalination and Water Treatment, 44, 15-28. https://doi.org/10.1080/19443994.2012.691699

[18] Ghernaout, D., Naceur, M.W. and Ghernaout, B. (2011) A Review of Electrocoagulation as a Promising Coagulation Process for Improved Organic and Inorganic Matters Removal by Electrophoresis and Electroflotation. Desalination and Water Treatment, 28, 287-320. https://doi.org/10.5004/dwt.2011.1493

[19] Ghernaout, D. and Naceur, M.W. (2011) Ferrate (VI): In Situ Generation and Water Treatment: A Review. Desalination and Water Treatment, 30, 319-332. https://doi.org/10.5004/dwt.2011.2217

[20] Ghernaout, D. and Ghernaout, B. (2012) On the Concept of the Future Drinking Water Treatment Plant: Algae Harvesting from the Algal Biomass for Biodiesel Production: A Review. Desalination and Water Treatment, 49, 1-18. https://doi.org/10.1080/19443994.2012.708191

[21] Kellali, Y. and Ghernaout, D. (2019) Physicochemical and Algal Study of Three Dams (Algeria) and Removal of Microalgae by Enhanced Coagulation. Applied Engineering, 3, 56-64.

[22] Irki, S., Ghernaout, D., Naceur, M.W., Alghamdi, A. and Aichouni, M. (2018) Decolorizing Methyl Orange by Fe-Electrocoagulation Process: A Mechanistic Insight. International Journal of Environmental Chemistry, 2, 18-28. https://doi.org/10.11648/j.ijec.20180201.14

[23] Ghernaout, D., Laribi, C., Alghamdi, A., Ghernaout, B., AitMessaoudene, N. and Aichouni, M. (2018) Decolorization of BF Cibacete Blue (CB) and Red Solophenyle 3BL (RS) Using Aluminum Sulfate and Ferric Chloride. World Journal of Applied Chemistry, 3, 32-40. https://doi.org/10.11648/j.wjac.20180302.11

[24] Ghernaout, D. (2017) Entropy in the Brownian Motion (BM) and Coagulation Background. Colloid and Surface Science, 2, 143-161.

[25] Irki, S., Ghernaout, D. and Naceur, M.W. (2017) Decolourization of Methyl Orange (MO) by Electrocoagulation (EC) Using Iron Electrodes under a Magnetic Field (MF). Desalination and Water Treatment, 79, 368-377. https://doi.org/10.5004/dwt.2017.20797

[26] Ghernaout, D. (2017) Environmental Principles in the Holy Koran and the Sayings of the Prophet Muhammad. American Journal of Environmental Protection, 6, 75-79. https://doi.org/10.11648/j.ajep.20170603.13

[27] Ghernaout, D. (2019) Reviviscence of Biological Wastewater Treatment: A Review. Applied Engineering, 3, 46-55.

[28] Ghernaout, D., Badis, A., Braikia, G., Matâam, N., Fekhar, M., Ghernaout, B. and 
Boucherit, A. (2017) Enhanced Coagulation for Algae Removal in a Typical Algeria Water Treatment Plant. Environmental Engineering and Management Journal, 16, 2303-2315. https://doi.org/10.30638/eemj.2017.238

[29] Ghernaout, D. (2019) Virus Removal by Electrocoagulation and Electrooxidation: New Findings and Future Trends. Journal of Environmental Science and Allied Research, 85-90.

[30] Ghernaout, D. (2019) Electrocoagulation Process for Microalgal Biotechnology: A Review. Applied Engineering, 3, 85-94.

[31] Boucherit, A., Moulay, S., Ghernaout, D., Al-Ghonamy, A.I., Ghernaout, B., Naceur, M.W., AitMessaoudene, N., Aichouni, M., Mahjoubi, A.A. and Elboughdiri, N.A. (2015) New Trends in Disinfection By-Products Formation upon Water Treatment. Journal of Research \& Developments in Chemistry, 2015, Article ID: 628833. https://doi.org/10.5171/2015.628833

[32] Ghernaout, D. and Boucherit, A. (2015) Review of Coagulation's Rapid Mixing for NOM Removal. Journal of Research \& Developments in Chemistry, 2015, Article ID: 926518. https://doi.org/10.5171/2015.926518

[33] Ghernaout, D., Ghernaout, B. and Kellil, A. (2009) Natural Organic Matter Removal and Enhanced Coagulation as a Link between Coagulation and Electrocoagulation. Desalination and Water Treatment, 2, 203-222. https://doi.org/10.5004/dwt.2009.116

[34] Ghernaout, D., Ghernaout, B., Saiba, A., Boucherit, A. and Kellil, A. (2009) Removal of Humic Acids by Continuous Electromagnetic Treatment Followed by Electrocoagulation in Batch Using Aluminium Electrodes. Desalination, 239, 295-308. https://doi.org/10.1016/j.desal.2008.04.001

[35] Ghernaout, D., Al-Ghonamy, A.I., AitMessaoudene, N., Aichouni, M., Naceur, M.W., Benchelighem, F.Z. and Boucherit, A. (2015) Electrocoagulation of Direct Brown 2 (DB) and BF Cibacete Blue (CB) Using Aluminum Electrodes. Separation Science and Technology, 50, 1413-1420. https://doi.org/10.1080/01496395.2014.982763

[36] Ghernaout, D., Benblidia, C. and Khemici, F. (2015) Microalgae Removal from Ghrib Dam (AinDefla, Algeria) Water by Electroflotation Using Stainless Steel Electrodes. Desalination and Water Treatment, 54, 3328-3337. https://doi.org/10.1080/19443994.2014.907749

[37] Ghernaout, D., Al-Ghonamy, A.I., Irki, S., Grini, A., Naceur, M.W., Ait Messaoudene, N. and Aichouni, M. (2014) Decolourization of Bromophenol Blue by Electrocoagulation Process. Trends in Chemical Engineering, 15, 29-39.

[38] Ghernaout, D., Al-Ghonamy, A.I., Naceur, M.W., AitMessaoudene, N. and Aichouni, M. (2014) Influence of Operating Parameters on Electrocoagulation of C.I. Disperse Yellow 3. Journal of Electrochemical Science and Engineering, 4, 271-283. https://doi.org/10.5599/jese.2014.0065

[39] Ghernaout, D., Irki, S. and Boucherit, A. (2014) Removal of $\mathrm{Cu}^{2+}$ and $\mathrm{Cd}^{2+}$, and Humic Acid and Phenol by Electrocoagulation Using Iron Electrodes. Desalination and Water Treatment, 52, 3256-3270. https://doi.org/10.1080/19443994.2013.852484

[40] Ghernaout, D., Naceur, M.W. and Aouabed, A. (2011) On the Dependence of Chlorine By-Products Generated Species Formation of the Electrode Material and Applied Charge during Electrochemical Water Treatment. Desalination, 270, 9-22. https://doi.org/10.1016/j.desal.2011.01.010

[41] Ghernaout, D., Mariche, A., Ghernaout, B. and Kellil, A. (2010) Electromagnetic 
Treatment-Bi-Electrocoagulation of Humic Acid in Continuous Mode Using Response Surface Method for Its Optimization and Application on Two Surface Waters, Desalination and Water Treatment, 22, 311-329. https://doi.org/10.5004/dwt.2010.1120

[42] Belhout, D., Ghernaout, D., Djezzar-Douakh, S. and Kellil, A. (2010) Electrocoagulation of a Raw Water of Ghrib Dam (Algeria) in Batch Using Iron Electrodes. Desalination and Water Treatment, 16, 1-9. https://doi.org/10.5004/dwt.2010.1081

[43] Saiba, A., Kourdali, S., Ghernaout, B. and Ghernaout, D. (2010) In Desalination, from 1987 to 2009, the Birth of a New Seawater Pretreatment Process: Electrocoagulation-An Overview. Desalination and Water Treatment, 16, 201-217. https://doi.org/10.5004/dwt.2010.1094

[44] Ghernaout, D., Ghernaout, B., Boucherit, A., Naceur, M.W., Khelifa, A. and Kellil, A. (2009) Study on Mechanism of Electrocoagulation with Iron Electrodes in Idealised Conditions and Electrocoagulation of Humic Acids Solution in Batch Using Aluminium Electrodes. Desalination and Water Treatment, 8, 91-99. https://doi.org/10.5004/dwt.2009.668

[45] Ghernaout, D., Ghernaout, B. and Boucherit, A. (2008) Effect of pH on Electrocoagulation of Bentonite Suspensions in Batch Using Iron Electrodes. Journal of Dispersion Science and Technology, 29, 1272-1275. https://doi.org/10.1080/01932690701857483

[46] Ghernaout, D., Badis, A., Ghernaout, B. and Kellil, A. (2008) Application of Electrocoagulation in Escherichia coli Culture and Two Surface Waters. Desalination, 219, 118-125. https://doi.org/10.1016/j.desal.2007.05.010

[47] Ghernaout, D., Al-Ghonamy, A.I., Naceur, M.W., Boucherit, A., Messaoudene, N.A., Aichouni, M., Mahjoubi, A.A. and Elboughdiri, N.A. (2015) Controlling Coagulation Process: From Zeta Potential to Streaming Potential. American Journal of Environmental Protection, 4, 16-27. https://doi.org/10.11648/j.ajeps.s.2015040501.12

[48] Ghernaout, D., Al-Ghonamy, A.I., Boucherit, A., Ghernaout, B., Naceur, M.W., AitMessaoudene, N., Aichouni, M., Mahjoubi, A.A. and Elboughdiri, N.A. (2015) Brownian Motion and Coagulation Process. American Journal of Environmental Protection, 4, 1-15. https://doi.org/10.11648/j.ajeps.s.2015040501.11

[49] Ghernaout, D. (2015) The Hydrophilic/Hydrophobic Ratio vs. Dissolved Organics Removal by Coagulation: A Review. Journal of King Saud University-Science, 26, 169-180. https://doi.org/10.1016/j.jksus.2013.09.005

[50] Ghernaout, D., Moulay, S., AitMessaoudene, N., Aichouni, M., Naceur, M.W. and Boucherit, A. (2014) Coagulation and Chlorination of NOM and Algae in Water Treatment: A Review. International Journal of Environmental Monitoring and Analysis, 2, 23-34. https://doi.org/10.11648/j.ijema.s.2014020601.14

[51] Ghernaout, D., Alghamdi, A., Aichouni, M. and Touahmia, M. (2018) The Lethal Water Tri-Therapy: Chlorine, Alum, and Polyelectrolyte. World Journal of Applied Chemistry, 3, 65-71. https://doi.org/10.11648/j.wjac.20180302.14

[52] Djezzar, S., Ghernaout, D., Cherifi, H., Alghamdi, A., Ghernaout, B. and Aichouni, M. (2018) Conventional, Enhanced, and Alkaline Coagulation for Hard Ghrib Dam (Algeria) Water. World Journal of Applied Chemistry, 3, 41-55. https://doi.org/10.11648/j.wjac.20180302.12

[53] Ghernaout, D. (2017) Water Treatment Chlorination: An Updated Mechanistic Insight Review. Chemistry Research Journal, 2, 125-138.

[54] WHO (World Health Organization). Potable Reuse, Guidance for Producing Safe 
Drinking-Water, 2017.

https://apps.who.int/iris/bitstream/handle/10665/258715/9789241512770-eng.pdf;js essionid=E19EC5088893FDF2686A388E31D779DD? sequence $=1$

[55] Ghernaout, D., Alshammari, Y. and Alghamdi, A. (2018) Improving Energetically Operational Procedures in Wastewater Treatment Plants. International Journal of Advanced and Applied Sciences, 5, 64-72. https://doi.org/10.21833/ijaas.2018.09.010

[56] Ghernaout, D. (2019) Disinfection via Electrocoagulation Process: Implied Mechanisms and Future Tendencies. EC Microbiology, 15, 79-90.

[57] Ghernaout, D. and Elboughdiri, N. (2019) Iron Electrocoagulation Process for Disinfecting Water: A Review. Applied Engineering, 3, 154-158.

[58] Ghernaout, D. and Elboughdiri, N. (2019) Electrocoagulation Process Intensification for Disinfecting Water: A Review. Applied Engineering, 3, 140-147.

[59] Ghernaout, D. (2019) Electrocoagulation and Electrooxidation for Disinfecting Water: New Breakthroughs and Implied Mechanisms. Applied Engineering, 3, 125-133.

[60] Ghernaout, D. (2018) Disinfection and DBPs Removal in Drinking Water Treatment: A Perspective for a Green Technology. International Journal of Advanced and Applied Sciences, 5, 108-117. https://doi.org/10.21833/ijaas.2018.02.018

[61] Ghernaout, D. and Ghernaout, B. (2010) From Chemical Disinfection to Electrodisinfection: The Obligatory Itinerary? Desalination and Water Treatment, 16, 156-175. https://doi.org/10.5004/dwt.2010.1085

[62] Quist-Jensen, C.A., Macedonio, F. and Drioli, E. (2015) Membrane Technology for Water Production in Agriculture: Desalination and Wastewater Reuse. Desalination, 364, 17-32. https://doi.org/10.1016/j.desal.2015.03.001

[63] Ghernaout, D. (2019) Brine Recycling: Towards Membrane Processes as the Best Available Technology. Applied Engineering, 3, 71-84.

[64] Ghernaout, D. (2013) Advanced Oxidation Phenomena in Electrocoagulation Process: A Myth or a Reality? Desalination and Water Treatment, 51, 7536-7554. https://doi.org/10.1080/19443994.2013.792520

[65] Rizzo, L., Malato, S., Antakyali, D., Beretsou, V.G., Đolić, M.B., Gernjak, W., Heath, E., Ivancev-Tumbas, I., Karaolia, P., Ribeiro, A.R.L., Mascolo, G., McArdell, C.S., Schaar, H., Silva, A.M.T. and Fatta-Kassinos, D. (2019) Consolidated vs New Advanced Treatment Methods for the Removal of Contaminants of Emerging Concern from Urban Wastewater. Science of the Total Environment, 655, 986-1008. https://doi.org/10.1016/j.scitotenv.2018.11.265

[66] Ghernaout, D., Aichouni, M. and Alghamdi, A. (2018) Applying Big Data (BD) in Water Treatment Industry: A New Era of Advance. International Journal of Advanced and Applied Sciences, 5, 89-97. https://doi.org/10.21833/ijaas.2018.03.013

[67] Reverberi, A.P., Maga, L., Cerrato, C. and Fabiano, B. (2014) Membrane Processes for Water Recovery and Decontamination. Current Opinion in Chemical Engineering, 6, 75-82. https://doi.org/10.1016/j.coche.2014.10.004

[68] AitMessaoudene, N., Naceur, M.W., Ghernaout, D., Alghamdi, A. and Aichouni, M. (2018) On the Validation Perspectives of the Proposed Novel Dimensionless Fouling Index. International Journal of Advanced and Applied Sciences, 5, 116-122. https://doi.org/10.21833/ijaas.2018.07.014

[69] Ghernaout, D., Alshammari, Y., Alghamdi, A., Aichouni, M., Touahmia, M. and AitMessaoudene, N. (2018) Water Reuse: Extenuating Membrane Fouling in Membrane Processes. International Journal of Environmental Chemistry, 2, 1-12. 
https://doi.org/10.11648/j.ajche.20180602.12

[70] Ghernaout, D., El-Wakil, A., Alghamdi, A., Elboughdiri, N. and Mahjoubi, A. (2018) Membrane Post-Synthesis Modifications and How It Came about. International Journal of Advanced and Applied Sciences, 5, 60-64. https://doi.org/10.21833/ijaas.2018.02.010

[71] Ghernaout, D., Alghamdi, A., Touahmia, M., Aichouni, M. and AitMessaoudene, N. (2018) Nanotechnology Phenomena in the Light of the Solar Energy. Journal of Energy, Environmental \& Chemical Engineering, 3, 1-8. https://doi.org/10.11648/j.jeece.20180301.11

[72] Irki, S., Ghernaout, D., Naceur, M.W., Alghamdi, A. and Aichouni, M. (2018) Decolorization of Methyl Orange (MO) by Electrocoagulation (EC) Using Iron Electrodes under a Magnetic Field (MF). II. Effect of Connection Mode. World Journal of Applied Chemistry, 3, 56-64. https://doi.org/10.11648/j.wjac.20180302.13

[73] Ghernaout, B., Ghernaout, D. and Saiba, A. (2010) Algae and Cyanotoxins Removal by Coagulation/Flocculation: A Review. Desalination and Water Treatment, 20, 133-143. https://doi.org/10.5004/dwt.2010.1202

[74] Ghernaout, D. (2017) Reverse Osmosis Process Membranes Modeling: A Historical Overview. Journal of Civil, Construction and Environmental Engineering, 2, 112-122.

[75] Ghernaout, D. and El-Wakil, A. (2017) Requiring Reverse Osmosis Membranes Modifications: An Overview. American Journal of Chemical Engineering, 5, 81-88. https://doi.org/10.11648/j.ajche.20170504.15

[76] Alshammari, Y., Ghernaout, D., Aichouni, M. and Touahmia, M. (2018) Improving Operational Procedures in Riyadh's (Saudi Arabia) Water Treatment Plants Using Quality Tools. Applied Engineering, 2, 60-71.

[77] Ghernaout, D. (2019) Greening Cold Fusion as an Energy Source for Water Treatment Distillation: A Perspective. American Journal of Quantum Chemistry and Molecular Spectroscopy, 3, 1-5.

[78] Ghernaout, D. (2017) Microorganisms' Electrochemical Disinfection Phenomena. EC Microbiology, 9, 160-169.

[79] Ipek, I., Kabay, N. and Yüksel, M. (2017) Separation of Bisphenol A and Phenol from Water by Polymeradsorbents: Equilibrium and Kinetics Studies. Journal of Water Process Engineering, 16, 206-211. https://doi.org/10.1016/j.jwpe.2017.01.006

[80] Vilela, C.L.S., Bassin, J.P. and Peixoto, R.S. (2018) Water Contamination by Endocrine Disruptors: Impacts, Microbiological Aspects and Trends for Environmental Protection. Environmental Pollution, 235, 546-559.

https://doi.org/10.1016/j.envpol.2017.12.098

[81] Jiang, L., Yang, J. and Chen, J. (2010) Isolation and Characteristics of 17beta-Estradiol-Degrading Bacillus spp. Strains from Activated Sludge. Biodegradation, 21, 729-736. https://doi.org/10.1007/s10532-010-9338-Z

[82] Guieysse, B. and Norvill, Z.N. (2014) Sequential Chemical-Biological Processes for the Treatment of Industrial Wastewaters: Review of Recent Progresses and Critical Assessment. Journal of Hazardous Materials, 267, 142-152.

https://doi.org/10.1016/j.jhazmat.2013.12.016

[83] Ghernaout, D., Simoussa, A., Alghamdi, A., Ghernaout, B., Elboughdiri, N., Mahjoubi, A., Aichouni, M. and El-Wakil, A.E.A. (2018) Combining Lime Softening with Alum Coagulation for Hard Ghrib Dam Water Conventional Treatment. International Journal of Advanced and Applied Sciences, 5, 61-70.

https://doi.org/10.21833/ijaas.2018.05.008 
[84] Ghernaout, D. (2018) Electrocoagulation Process: Achievements and Green Perspectives. Colloid and Surface Science, 3, 1-5. https://doi.org/10.11648/j.css.20180301.11

[85] Ghernaout, D. (2019) Greening Electrocoagulation Process for Disinfecting Water. Applied Engineering, 3, 27-31.

[86] Ghernaout, D., Alghamdi, A. and Ghernaout, B. (2019) Microorganisms' Killing: Chemical Disinfection vs. Electrodisinfection. Applied Engineering, 3, 13-19.

[87] Ghernaout, D., Aichouni, M. and Touahmia, M. (2019) Mechanistic Insight into Disinfection by Electrocoagulation: A Review. Desalination and Water Treatment, 141, 68-81. https://doi.org/10.5004/dwt.2019.23457

[88] Ghernaout, D., Touahmia, M. and Aichouni, M. (2019) Disinfecting Water: Electrocoagulation as an Efficient Process. Applied Engineering, 3, 1-12.

[89] Ghernaout, D. (2019) Aeration Process for Removing Radon from Drinking Water: A Review. Applied Engineering, 3, 32-45.

[90] Scruggs, C.E. and Thomson, B.M. (2017) Opportunities and Challenges for Direct Potable Water Reuse in Arid Inland Communities. Journal of Water Resources Planning and Management, 143, Article ID: 04017064. https://doi.org/10.1061/(ASCE)WR.1943-5452.0000822

[91] Hummer, N. and Eden, S. (2016) "Potable Reuse of Water" Arroyo. University of Arizona Water Resources Research Center, Tucson.

http://wrrc.arizona.edu/publications/arroyo-newsletter/arroyo-2016-Potable-Reuseof-Water

[92] Ghernaout, D. and Elboughdiri, N. (2019) Mechanistic Insight into Disinfection Using Ferrate (VI). Open Access Library Journal, 6, e5946. 